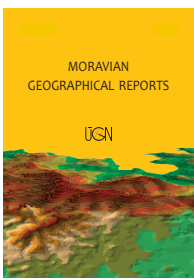

MORAVIAN GEOGRAPHICAL REPORTS

\title{
Technological relatedness, knowledge space and smart specialisation: The case of Germany
}

\author{
Jana VLČKOVÁ a ${ }^{\text {* }}$, Nikola KASPŘÍKOVÁ ${ }^{\mathrm{b}}$, Markéta VLČKOVÁ a
}

\begin{abstract}
The level of technological specialisation in the regions of Germany is assessed in this paper, as well as how such specialisation has evolved over time. Further, in three selected regions (Munich, Düsseldorf and Oberes Elbtal/Osterzgebirge), the knowledge space is explored in detail and compared to existing smart specialisation strategies. Average relatedness and knowledge space based upon EPO patent applications are used to measure the specialisation and technology trajectories of the German regions. Between three periods 1988-1992, 1998-2002 and 2008-2012, the specialisation of Germany based on EPO patent applications increased by $10 \%$, despite a decline in many regions. Machinery and transportation industries have increased their significance. The assessment of regional smart specialisation strategies in the three German states shows that the methodology in terms of the identification of prospective industries is largely variegated and insufficiently developed. More attention should also be given to the choice of an appropriate geographical level of aggregation for analysis. Knowledge relatedness and knowledge complexity could be used as methodological tools for selecting prospective industries in smart specialisation strategies.
\end{abstract}

Keywords: patents, technological relatedness, regional specialisation, smart specialisation, Germany

Article history: Received 15 August 2017; Accepted 4 June 2018; Published 30 June 2018

\section{Introduction}

Innovations are considered to be the main driver of economic growth (Aghion and Howitt, 1990). At the same time, innovation activity is spread unevenly and it is one of the most geographically-concentrated economic activities. Europe lags behind the United States in terms of productivity and this is, among other factors, related to a lack of industrial and technological specialisation (Ortega-Argilés, 2012): hence, the discussion about which sources of growth, countries should focus upon. For such purposes, the European Union (EU) implemented the concept of smart specialisation, which puts an emphasis on the most efficient use of public financial resources dedicated to Research and Development (R\&D).

Whereas significant attention has been given to the processes of knowledge creation in a spatial context (Audretsch and Feldman, 1996; Asheim and Gertler, 2005), considerably less attention is given to the types of knowledge created in specific locations, how they develop over time and how they affect future development. The recently emerging evolutionary economic geography attempts to explain the change in spatial and regional structures through endogenous technological innovation. The concept of knowledge relatedness focuses on the types of knowledge in specific locations and how existing capabilities affect future technology trajectories (see for example: Rigby, 2015; Kogler et al., 2017). The recently introduced smart specialisation policy has been implemented in the EU regions, although it has been criticised for its inadequately developed theory as well as its methodology (Morgan, 2015; Santoalha, 2016). This paper aims to add to existing research by providing an empirical validation of the knowledge relatedness concept in Germany, and by relating the observed technological trajectories to existing regional smart specialisation strategies.

The aim of this paper is firstly to examine the evolution of knowledge production in German regions, with particular regard to how technologically specialised they are and how this specialisation has evolved over time. This is based on the analysis of European Patents Office (EPO) patents, specifically on the average relatedness index following Kogler et al. (2017), as well as the visualisation of knowledge relatedness in the so-called knowledge space. Following that, in three selected regions the knowledge space is explored in detail and compared to existing smart specialisation strategies.

\footnotetext{
${ }^{a}$ Faculty of International Relations, University of Economics in Prague, Prague, Czech Republic (*corresponding author: J. Vlčková, e-mail: jana.vlckova@vse.cz)

${ }^{\mathrm{b}}$ Faculty of Informatics and Statistics, University of Economics in Prague, Prague, Czech Republic
} 
The first section summarises existing research on knowledge relatedness and smart specialisation. In the second section, the data are described and there is an explanation of the methodology. Subsequently, results are shown: the situation is evaluated at the country-level; then regional specialisation is considered; and this is followed by an analysis of the situation in three selected spatial planning regions. This analysis is put into the context of prospective industries and existing Research and Innovation Strategies for Smart Specialisation (RIS3). Concluding remarks are found in the final section.

\section{Theoretical background: innovation, specialisation and relatedness}

The role of innovation in economic growth is now widely accepted in economic theory (Aghion and Howitt, 1990; Audretsch and Feldman, 1996). The separation of production and design as parts of globalisation processes has further reinforced the importance of knowledge production. At the same time, the spatial distribution of innovation activity is very uneven, largely due to the limited diffusion of tacit knowledge over larger distances (Gertler, 2003). Innovation is one of the most spatially concentrated activities and geographical proximity in the creation of knowledge continues to be important (Sonn and Storper, 2008). Spatial proximity is an important but not sufficient condition, though, as other forms of proximity have been identified (Boschma, 2005).

The innovation process is a complex social activity involving various types of knowledges and actors, and regions differ considerably in their innovation characteristics (Iammariono and McCann, 2006). Regional capabilities have been found to be more important for knowledge creation and regional specialisation than national ones (Maskell and Malberg, 2007), which has been confirmed by several studies on specific regions (e.g. Saxenian, 1996). How related new industries are to existing knowledge in a region has already been studied by Teece et al. (1994), Breschi et al. (2003) or Leten et al. (2007) - for an overview see Joo and Kim (2010). Knowledge relatedness has been used to find the connection between technological diversification and firms' technological performance (e.g. Tanriverdi and Venkatraman, 2005). At the company level, absorptive capacity is crucial (Cohen and Levinthal, 1990). Questions remain on whether specialisation (so-called Marshall-Arrow-Romer (MAR) externalities) or diversity (Jacobs externalities) foster more economic growth in cities and regions, though existing research provides evidence for both Jacobian and MAR externalities (see Beaudry and Schiffauerova, 2009).

Evolutionary Economic Geography explores the role of knowledge relatedness in regional development. Evolutionary geography is based on the fact that the production of knowledge stems from specific patterns in a region, patterns which have developed over time (Frenken and Boschma, 2007). Knowledge creation and innovation activity are, in general, path- dependent processes (Martin and Sunley, 2006). Tangible and intangible assets are present in the firm, and over time leak into the region. Therefore, the identification of relatedness between technologies/products/ industries and existing capabilities in the region can help to predict future possible technological trajectories. Following the Hidalgo product space concept, researchers focus now more on relatedness between economic activities and how these affect regional development and the emergence of new industries. Based on country exports, Hidalgo et al. (2007) showed how an existing industrial structure can affect future diversification. In recent studies, Neffke et al. (2011) explored the importance of related variety in Sweden, as did Boschma and Iammarino (2009) in Italy and Boschma et al. (2013) in Spain. Knowledge relatedness has been mapped in US cities (Rigby, 2015; Kogler et al., 2013; Balland and Rigby, 2017), the EU15 (Kogler et al., 2017; Vlčková and Kaspř́ḱková, 2015) and Ireland (Kogler and Whittle, 2017). These studies have demonstrated that technologies which are closer to the existing knowledge base in the region are more likely to develop there, than those which are unrelated. This paper adds to existing research on knowledge (technological) relatedness by providing an empirical validation of technological relatedness in German regions.

The findings of the relatedness research are very useful for the smart specialisation policy. In Europe, the lack of industrial specialisation has been considered one of the obstacles to productivity growth (Ortega-Argilés, 2012), despite increasing specialisation in Europe over time (e.g. Brülhartart and Traeger, 2005). Furthermore, Forey et al. (2009) argue that in many European regions there is a weak correlation between $R \& D$ capabilities, training specialisation and industrial structure (see also Coronado et al., 2017). Large differences in innovation output across Europe have been demonstrated, although less attention has been paid to knowledge specialisation, especially in the context of economic integration. This has changed with the introduction of the smart specialisation concept. This concept emerged in academia (Foray et al., 2009) and it has been adopted by policymakers in the EU. The aim of smart specialisation is "to boost regional innovation in order to achieve economic growth and prosperity, by enabling regions to focus on their strengths" (European Commission, 2016). The smart specialisation concept does not aim to make the economic structure of regions more specialised; rather, it is based on the identification of core competencies and potential complementarities in order to make the innovation process more efficient. It emphasises the role of knowledge diffusion processes between sectors, activities and occupations, and avoids "one-size-fitsall" solutions and the automatic prioritisation of hightechnology sectors, which are not suitable for all regions. It should among other things overcome the fragmentation and duplication of public investments for Research and Development (R\&D) in Europe, the lack of synergies between knowledge economy actors within regions, and the insufficient abilities to build external knowledge networks (Nauwelaers et al., 2014).

What differentiates smart specialisation from traditional industrial and innovation policies is above all a process defined as "entrepreneurial discovery" - an interactive process whereby market forces and the private sector discover and produce information on new innovation activities, and the government evaluates their outputs and supports those that have the greatest potential (OECD, 2013). All EU regions must now develop smart specialisation strategies in order to qualify for structural funding.

The smart specialisation policy requires new measures to identify the main competencies of regions, usually through a combination of qualitative and quantitative data. This is because technological trajectories in most regions have been found to be rather stable (Rigby and Essletzbichler, 1997). Region-specific capabilities are crucial for the identification of prospective industries. This seems to be the main problem of smart specialisation, because 
there is not yet either sufficient theoretical or empirical bases for the implementation of a smart specialisation policy (Morgan, 2015; Santoalha, 2016). Kogler and Whittle (2017) point out that the relatedness research can help tackle some of these issues as it can be used to identify strengths and knowledge capabilities, identify sectors which should be abandoned, possibly predict future trajectories and how to bridge the gap between two technologies by recombination of existing ones and the emergence of new technological trajectories. The "value" of knowledge also differs. Knowledge (technology) complexity is closely related to economic benefits, since more complex knowledge is based on a larger set of capabilities and such regions grow more (Balland and Rigby, 2007; Hidalgo et al., 2007). Diversifying into complex technologies is difficult for many regions, though. Whereas knowledge relatedness focuses on the costs of moving from one technology to another, knowledge complexity focuses on the potential benefits (Balland et al., 2017). Diversification depends on current capabilities and the proximity of new technological possibilities, but knowledge production in other locations is also important (Rigby, 2015), as is stressed in the local buzz and global pipelines conceptual framework (Bathelt et al., 2004).

Since tacit knowledge and path dependence play a crucial role in the innovation process (Gertler, 2003), Germany's historical industrial orientation significantly affects its current R\&D and innovation activities. Germany has the highest number of patents in Europe, above average R\&D expenditures (2.9\% of GDP) and close links between schools and companies (vocational training). Due to their very distinct histories, we can expect large variations between the former socialist German Democratic Republic (East) and the Western market-based system of Germany In 2006, Germany implemented the High-Tech Strategy and its update in 2011 introduced the term Industrie 4.0, describing a focus on automatisation and digitalisation in manufacturing. There are several studies exploring R\&D and innovation in Germany (e.g. Peters, 2008; Beise and Stahl, 1999), as well as innovation policies (e.g. Kiese, 2008 Kiese and Wrobel, 2011; Kroll et al., 2016). To the best of our knowledge, the regional (knowledge) specialisation within Germany has been studied only by Suedekum (2006), who found that between 1993 and 2001 there was neither a process of regional specialisation nor one of the geographical concentration of industries in Germany. Regional specialisation has also been explored as a part of the RIS3 documents.

\section{Data and methodology: patents and knowledge relatedness}

Measuring knowledge relatedness and its visualisation in knowledge space will enable us to assess the specialisation of German regions and the identification of prospective industries in line with the concept of smart specialisation. In general, it is difficult to measure knowledge and technology (Pavitt, 1982). This is because it is more a social rather than a technical process. Several input and output indicators of innovation activity have been used (e.g. $R \& D$ investment, patents, R\&D workers), although all of them suffer from several limitations. Patents reflect the knowledge base of the region, are unique in the extent of detail involved and in the breadth of their geographical and historical coverage. Nonetheless, not all patented inventions are innovations, not all inventions are patentable, and many inventions are never patented (Acs and Audretsch, 1989). There are also differences in the propensity to patent between industries, and the allocation of patents to the relevant industry is not easy (Grupp, 1998; Griliches, 1998). Countries specialising in manufacturing and ICT have a higher propensity to patent than countries with a large service sector, which engage more in trademark protection (OECD, 2011). Further, there are country differences in patenting activity (Cohen et al., 2002), and patents do not measure economic value (Hall et al., 2001; Schankerman and Pakes, 1986). Despite these limitations, patents have been widely used in economic research (e.g. Scherer, 1982; Griliches, 1998) and are a reliable measure of innovative activity at the industrial and regional level (Acs and Audretsch, 1989). Further, due to the strong manufacturing orientation of Germany, using patents is more suitable here than in many other countries.

We use patent applications from the OECD REGPAT database (OECD, 2016), which covers patent applications filed with the European Patent Office (EPO) relating to more than 5,500 regions. Although patent applications do not measure economic value and the value of most patents is negligible (Hall et al., 2001), using simple counts is sufficient since we are interested in innovation activity and technological relatedness. We use the date of patent applications (priority date) rather than that of patent grants, because the priority date is the closest to the invention activity. The country of the inventor is sed rather than the country of the patent owner, since we are interested in the innovation capabilities of regions. We only include inventors from Germany. If inventors are assigned to more countries (or regions), we divide the patent between inventors. We use three five-year periods to account for yearly variations: 1988-1992, 1998-2002, and 2008-2012. Knowledge relatedness is measured at NUTS1 (Bundesländer) and NUTS2 regions. Several NUTS1 are at the same time NUTS2 regions. We also provide a more detailed analysis in three of the 96 German spatial planning units: Munich, Düsseldorf and Oberes Elbtal/Osterzgebirge, where Dresden is located.

Indices used to measure technological specialisation and diversity, such as the Herfindahl index, expect the distance between sectors to be the same (Rigby, 2015), which is unsuitable for our purposes. Therefore, we use technological (knowledge) relatedness, which can be measured by patent citations or the probability of relations between technological fields (patent co-classification data). In this paper, knowledge relatedness is measured based on the patent categories each patent belongs to, based on Kogler et al. (2017). The classification of patents to industries has been problematic because patent categories do not correspond to industrial sectors. In this paper, we use the International Patent Classification (IPC) of 121 sub-categories and split them into 7 industrial categories, according to Kogler et al. (2017). These are different from the IPC categories, which do not reflect the industries accordingly. Each patent is then placed into one or more of the patent categories, which reflect the technological characteristics of the underlying knowledge. If a patent is split into 3 regions (one of them in Berlin) and two patent classes (e.g. A47 and B01), then the share of Berlin in class A47 will be (1/3) × (1/2).

The data from the REGPAT have a few limitations. For example, for the first period 1988-1992, the assignment of patents to the regions is often missing. Furthermore, there is a slight decline in the number of patents between 1998-2002 and 2008-2012, although there has been a slight increase in patent applications under EPO from Germany. This is 
related to the fact that information on patents is generally available 18 months after the priority date and thus some patent applications may be missing from the dataset. Since the major focus of this paper is on knowledge relatedness and smart specialisation, we assume this will not affect the overall results.

The knowledge space is used to demonstrate the specialisation of the region and the evolution of its technological specialisation (entry and exit into specific technological sectors), based on the visualisation of the relationship between individual patent categories. We follow the product space concept introduced by Hidalgo et al. (2007), which is based on the assumption that the specialisation of a country is related to the knowledge and capabilities present in a given country. This concept has also been used in other contexts such as mapping carbon dioxide emissions in trade (Vlčková et al., 2015). The relatedness between individual patent categories measures the co-occurrence of these categories in particular patents. We assume that the more often a patent belongs to two different patent categories the higher is the probability that these patent categories share a similar knowledge base.

The knowledge space maps how individual categories are related. The first symmetric matrix which includes the number of patents belonging to particular categories is prepared. This matrix of co-occurrences can then be used to derive a measure of relatedness between technological fields, and to provide a visualisation of relations between patent classes in the networks. Overall there are 121 patent classes, belonging to 7 different fields. We apply the same method as Kogler et al. (2017): we measure the knowledge relatedness based on the probability that an individual patent belongs to more categories. Let $P$ be the number of granted patents, $p$ be a particular patent and $i$ and $j$ patent categories. If a patent belongs to category $i$, then $F_{i p}=1$. If a patent does not belong to category $i$ then $F_{i p}=0$. The number of patents for category $i$ is $N_{i}=\sum_{p} F_{i p} . N_{i j}=\sum_{p} F_{i p} F_{j p}$ indicates the number of patents belonging to both category $i$ and category $j$. This is done for all 121 categories resulting in a $121 \times 121$ matrix, which indicates the number of patents belonging to both categories. Knowledge relatedness is also affected by the total number of patents belonging to a category. Thus a standardised matrix of co-occurrence $(S)$, which indicates technological relatedness between two different categories in a year, is created with the elements

$$
S_{i j}=N_{i j} / \sqrt{N_{i} * N_{j}}
$$

where the elements on the main diagonal of the matrix $S$ are set to 1 .

This was computed and used for the construction of knowledge networks (the knowledge space). With the help of Cytoscape software, the relations between the 121 patent categories are mapped. We use the Edge-weighted Forcedirected layout to position the nodes and edges in the network. Such a layout uses some kind of physical simulation that models the nodes as physical objects and the edges as springs connecting those objects together (Cytoscape, 2017). Nodes represent patent categories and the size of the nodes indicates the number of patents in the category. Patent categories with the same sections are marked with the same colour (see Fig. 1). Only the strongest relations are mapped.
To map the situation in the three selected regions in Section 4.3, we used revealed technological advantage (Archibugi and Pianta, 1992). Revealed technological advantage (RTA) measures whether a region has greater share of patents in the technology class compared to the whole sample (in our case Germany). RTA is based on a simple formula

$$
R T A=\left(\frac{P_{i r}}{P_{I r}}\right) /\left(\frac{P_{i R}}{P_{I R}}\right)
$$

where $P$ indicates the number of patents, $P_{i r}$ is the number of patents in category $i$ and region $r, P_{I r}$ is the total number of patents in region $r . P_{i R}$ is the number of all patents in category $i$ in all regions $R$ and $P_{I R}$ is the number of all patents in all regions. RTA $>1$ indicates specialisation in the technological field.

Whilst knowledge relatedness measures the relation between two patent categories, we also need to identify the average knowledge relatedness score (AR) for each region to assess the knowledge specialisation. Average relatedness is thus a summary measure of specialisation and enables the comparison of knowledge relatedness between regions, in patent sections and over time.

Higher average knowledge relatedness score indicates that patents are being generated in technological areas that are closer to one another in the knowledge space (patent classes tend to co-occur at a higher frequency). Lower AR scores indicate that patents that are distributed further apart in the knowledge space.

The average knowledge relatedness for a year $t$ and country $\mathrm{c}$ is calculated as

$$
\mathrm{AR}^{\mathrm{tc}}=\frac{\sum_{j} \sum_{i} S_{i i}^{t} * D_{i i}^{t, r}+\sum_{i} S_{i j}^{t} * 2 D_{i j}^{t, r}}{N^{t, r} *\left(N^{t, r}-1\right)} \text { for } i \neq j
$$

where $S_{i j}^{t}$ is the knowledge relatedness between patents in classes $i$ and $j, D_{i j}^{t, r}$ indicates the number of pairs of patents belonging to category $i$ and $j$ in a year $t$ and region $r, N^{t, r}$ is the total number of patents in a year $t$ and region $r$.

\section{Results: Technological specialisation in Germany and German regions}

\subsection{Technological specialisation in Germany}

Germany has the highest number of patent applications in Europe and globally it accounted for $15 \%$ of EPO patent applications in 2015, following the USA with $18 \%$ (OECD, 2017). Despite the growing number of patent applications from German inventors, its global share has been declining due to the rise of emerging markets such as China. The biggest patent applicants in Germany include firms like Siemens, Bosch and BASF. Germany has high labour productivity, the share of expenditures on R\&D reached $2.9 \%$ of GDP, and business R\&D accounted for $68 \%$ of these expenditures in 2015 (OECD, 2017). Within the EU, Germany has the highest number of innovative enterprises, but a relatively lower share of venture capital. The dual education system combining general transferable skills and structured learning on the job, is supportive for providing technical skills and a strong supply of graduates. There is also widespread cooperation between the public and business 
sectors, and private and public research complement each other (Beise and Stahl, 1999), such as the Max Planck Society or the Fraunhofer Society.

Germany dominates in medium-high-tech industries, particularly engineering industries, automobiles and chemicals, and also in environmental and energy technologies. The high number of patents is among other things explained by the above-average share of industries with a higher propensity to patent, such as ICT, the automobile industry, medical equipment and energy technology. In terms of patenting in the selected categories, there has been a notable increase in Machinery and transport over time. This category accounts for one third of all EPO applications. Electronics and Industrial processes both accounted for about 14\% of EPO applications in the latest period. Surprisingly, the categories which are associated with newer technologies such as Drugs and medicine, Electronics and Instruments, have risen only slightly or have stagnated over the past twenty years (see Tab. 1). This contrasts with the situation in the EU15 (see Kogler et al., 2017) and confirms the large and continuing specialisation of Germany in Machinery and transport. In spite of that, Germany continues to be also one of the main producers of Drugs and medicine.

In terms of specialisation (measured by average relatedness - AR) in Germany, there has been a slight rise over the whole period (by approximately 10\%), but a slight decline between the last two periods. Kogler et al. (2017) found increase in specialisation by over $30 \%$ in the EU15 regions although they examined the situation only until 2005 and several German regions have already witnessed decline in specialisation. This requires further research of the situation in EU states. In terms of AR within the categories the highest is in Drugs, medicine since there are only a few patent classes in this category. Average relatedness is also at a high level in Consumer goods, the smallest category. On the other hand, the smallest AR is in Machinery and transport and it is decreasing over time. This can be affected by the rising number of patent applications (relatively and absolutely) in this category. Overall an increase of AR has been found in most categories (Electronics, Instruments, Drugs, medicine and Consumer goods).

The growth in the Machinery, transport category is also confirmed by increasing R\&D expenditure. The highest and increasing business R\&D investment (BERD) intensity between 1995 and 2013 in Germany was in Motor vehicles, trailers and other transport equipment, and it accounted for a third of total German BERD. On the other hand, Electrical equipment and Chemicals and chemical products have decreasing BERD intensities (European Commission, 2016). The low levels of spending are in high-tech areas; pharmaceuticals, ICT, radio, TV and communication equipment, and medical precision and optical instruments. The service sector also has a relatively low research intensity (European Commission, 2016).

As the knowledge space indicates, there is an obvious clustering of patent classes within the same category over time (see Fig. 1). Some categories such as Industrial processes (blue) and Chemicals, materials (black) are getting closer to each another. This indicates that within these categories a more similar type of knowledge is being used. Also Machinery, transport (purple) is getting more dispersed over the knowledge space (also demonstrated through a decrease in AR), particularly closer to Instruments (green) and Electronics (red). This is probably related to the fact that Machinery, transport is increasingly using Instruments, such as optics and measuring technologies and ICT technologies from the Electronics category, and this trend is likely to accelerate with the ever-growing pace of digitisation. Drugs, medicine are clustering apart from the others, which is confirmed by the increasing AR within the group (see Tab. 1).

\subsection{Regional differences and patterns of specialisation}

We explore innovation activity in Germany using NUTS1 and NUTS2 regions. Over the period, the patent applications to EPO from German inventors have increased by $70 \%$. At the level of Bundesländer (NUTS1), there are very large differences between the former East and West German states. Whilst between 1988 and 1992, East German states (excluding Berlin) only accounted for 1 percent of all patent applications to EPO, in 2008-2012 it had increased to about 6\%.

Patent applications are concentrated primarily in southern Germany: in Bavaria (25\% of EPO applications), followed by Baden-Württemberg (24\%) and North Rhine-Westphalia $(22 \%)$. All these three regions have strong manufacturing traditions; in Baden-Württemberg, many TNCs are headquartered, such as Daimler AG, Robert Bosch GmbH and SAP SE, although mid-sized companies are the backbone of the economy. The Bavarian economy is associated mostly with the automotive industry (BMW, Audi, MAN), although

\begin{tabular}{|c|c|c|c|c|c|c|c|c|c|c|}
\hline \multirow[b]{2}{*}{ Category } & \multirow[b]{2}{*}{ 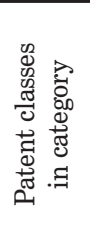 } & \multicolumn{3}{|c|}{ 1988-1992 } & \multicolumn{3}{|c|}{ 1998-2002 } & \multicolumn{3}{|c|}{ 2008-2012 } \\
\hline & & 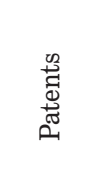 & 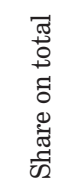 & 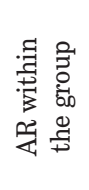 & 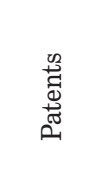 & 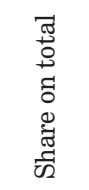 & 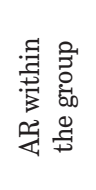 & 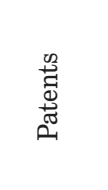 & 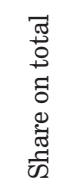 & 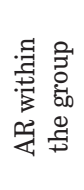 \\
\hline Electronics & 8 & 7,704 & $13 \%$ & 0.247 & 15,878 & $16 \%$ & 0.277 & 13,598 & $14 \%$ & 0.278 \\
\hline Instruments & 12 & 6,459 & $11 \%$ & 0.246 & 14,201 & $15 \%$ & 0.229 & 12,631 & $13 \%$ & 0.272 \\
\hline Chemicals, materials & 22 & 10,449 & $18 \%$ & 0.128 & 13,227 & $14 \%$ & 0.120 & 11,442 & $12 \%$ & 0.113 \\
\hline Drugs, medicine & 3 & 3,584 & $6 \%$ & 0.653 & 7,697 & $8 \%$ & 0.624 & 7,916 & $8 \%$ & 0.674 \\
\hline Industrial processes & 36 & 10,431 & $18 \%$ & 0.078 & 13,749 & $14 \%$ & 0.076 & 13,385 & $14 \%$ & 0.074 \\
\hline Machinery, transport & 32 & 16,731 & $29 \%$ & 0.097 & 30,114 & $31 \%$ & 0.104 & 32,296 & $34 \%$ & 0.088 \\
\hline Consumer goods & 8 & 1,802 & $3 \%$ & 0.367 & 2,696 & $3 \%$ & 0.404 & 3,062 & $3 \%$ & 0.425 \\
\hline Total & 121 & 57,159 & $100 \%$ & 0.030 & $\mathbf{9 7 , 5 6 2}$ & $100 \%$ & 0.034 & 94,330 & $100 \%$ & 0.033 \\
\hline
\end{tabular}

Tab. 1: Patent applications and average relatedness in the main categories

Source: authors' calculations based on data from OECD (2016) 


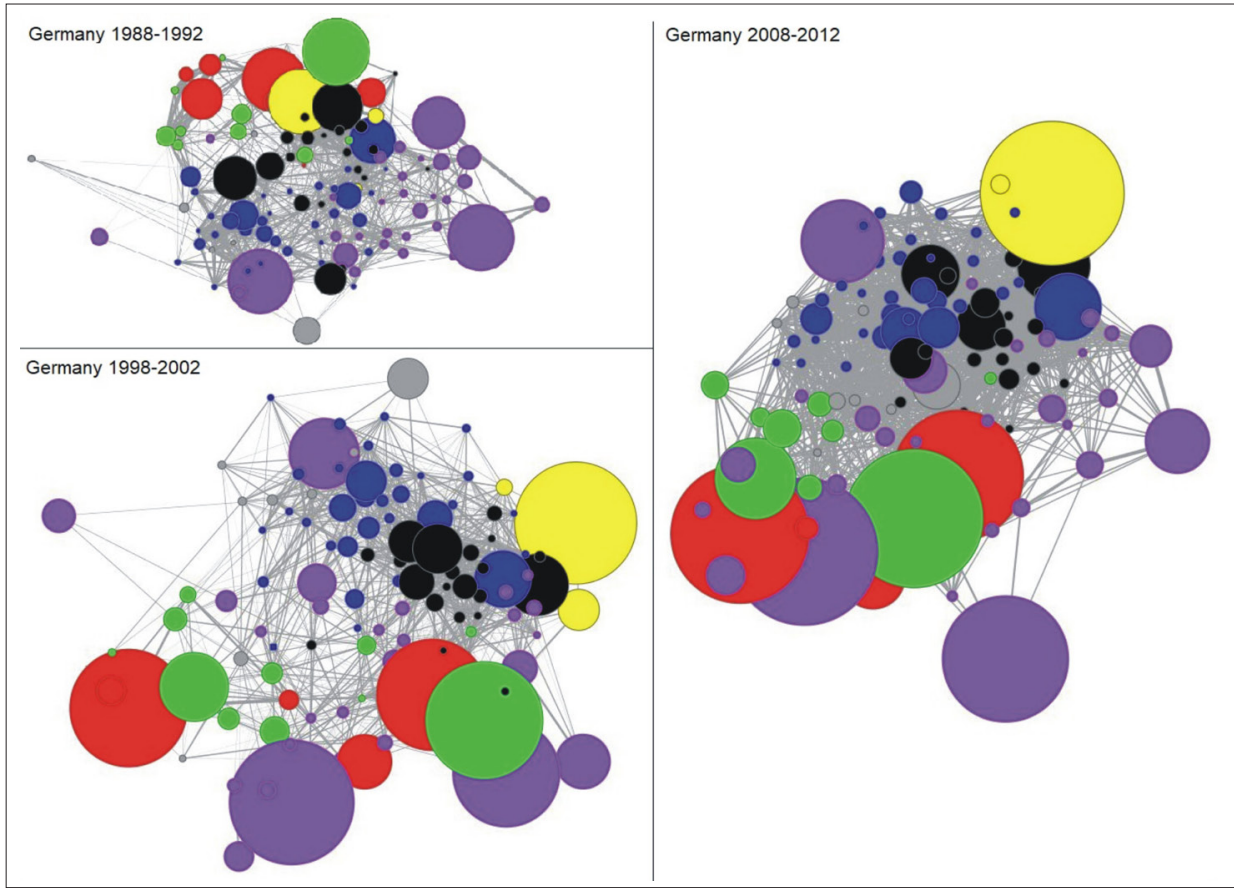

Fig. 1: Germany's knowledge space (Notes: Red = Electronics, Green = Instruments, Black = Chemicals, Materials, Yellow = Drugs, medicine, Blue = Industrial Processes, Purple = Machinery, transport, Grey = Consumer Goods. Size of the nodes indicate the number of patents. The biggest yellow node represents category A61-Medical or veterinary science; hygiene with 6301 patents)

Source: authors' calculations using data from OECD (2016)

the electronics industry is also significant. The Ruhr area, as one of the most important industrial regions despite significant economic restructuring in recent decades, is a part of North Rhine-Westphalia. On the other hand, the lowest shares of patents are in very small regions like Mecklenburg-Western Pomerania. Due to large variations in size, the relative numbers of patents per population are more testifying. Both Baden-Württemberg and Bavaria have the highest relative patenting activity, followed by Hessen. The lowest patenting rates can be found in the East-German states of Saxony-Anhalt, Mecklenburg-Western Pomerania and Saxony. The most specialised (highest AR) Bundesländer are the three city-states of Berlin, Bremen and Hamburg. This is line with the findings of existing studies that average relatedness is negatively related to urban/region sise (Kogler et al., 2013; Rigby, 2015).

The least specialised regions are North Rhine-Westphalia, Saxony-Anhalt and Saxony. Low levels of specialisation also occur in Bavaria. North Rhine-Westphalia and Bavaria are large states with highly diversified industrial structures, whereas in Saxony and Saxony-Anhalt low specialisation could be related to their communist history and continuing economic restructuring. Specialisation has increased in most states between 1988-1992 and 1998-2002. Between 1998-2002 and 2008-2012, however, specialisation slightly declined or remained stable in all states except Saarland and Bremen. There are large variations between the German states in terms of their population size, area, economic structure and patenting, as well as other indicators (such as R\&D expenditures, researchers and R\&D personnel). Therefore, we focus more on NUTS2 regions and specifically follow the situation in three German planning regions.

At the level of NUTS2, the highest number of patents is in Upper Bavaria (electronics and instruments, ICT), Stuttgart (electrical engineering, media industries),
Düsseldorf (telecommunications centre), Karlsruhe (a mix of innovative companies and well-established universities), and Darmstadt (chemical and pharmaceutical industry). These five regions are in the top ten of patent output in the EU and account for $37 \%$ of all patent applications in Germany. The highest increase over the period has been in the former East German regions and also in Bremen and Upper Palatinate. In terms of patents per population, the highest numbers are in Stuttgart, Tübingen, Middle Franconia and Upper Bavaria (all located in BadenWürttemberg and Bavaria). The lowest numbers are in Mecklenburg-Western-Pomerania and Saxony-Anhalt (both in East Germany). Other indicators show similar results. Expenditures on R\&D exceed 6\% of GDP in Stuttgart and Braunschweig and over $4 \%$ in Tübingen, Upper Bavaria and Karlsruhe, where leading universities and/or innovative companies are located. High expenditures are also recorded for Dresden (see Section 4.3 below). Very high numbers of researchers (relatively) are also located in Stuttgart, Upper Bavaria, Karlsruhe, and Braunschweig.

In terms of specialisation, the most specialised regions are not only Upper Palatinate and Lower Franconia but also the cities of Berlin, Bremen and Hamburg (see above). The least specialised are Münster and Chemnitz. Figure 2 demonstrates the specialisation of the regions. There are large variations across Germany and the most specialised remain in the central parts. There is no obvious trend. Some of the most innovative regions are highly specialised, such as Stuttgart and Darmstadt; others like Düsseldorf and Upper Bavaria are more technically diversified (see Section 4.3). As was the case with the NUTS1 level, most NUTS2 regions have also witnessed increasing specialisation between 1988-1992 and 1998-2002, with the exception of a few East-German regions with extremely low numbers of patent applications in the first period. Between 1998-2002 and 2008-2012 specialisation stagnated or declined. Only 


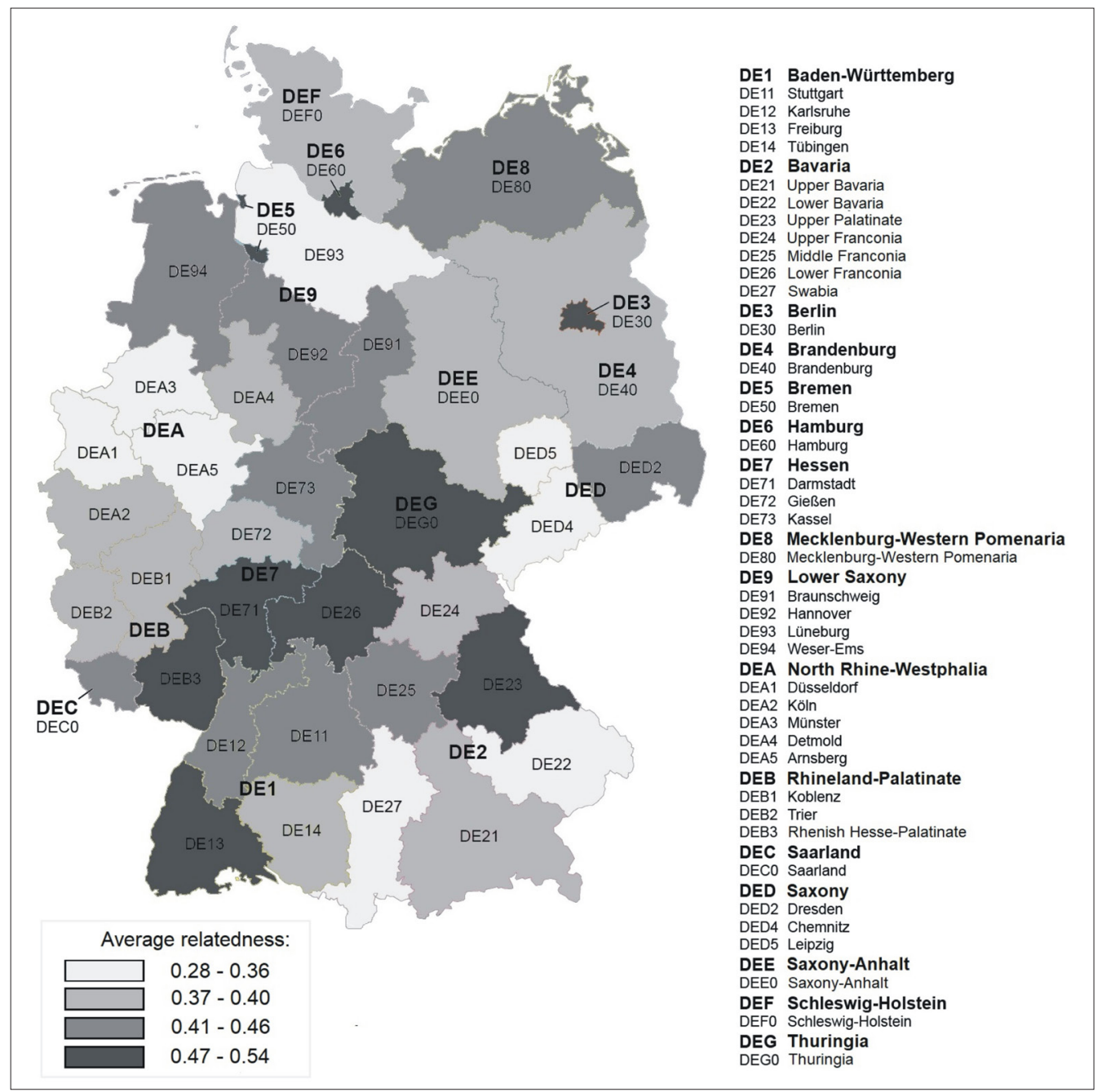

Fig. 2: Average technological relatedness in German NUTS2 regions Source: authors' elaboration using data from OECD (2016)

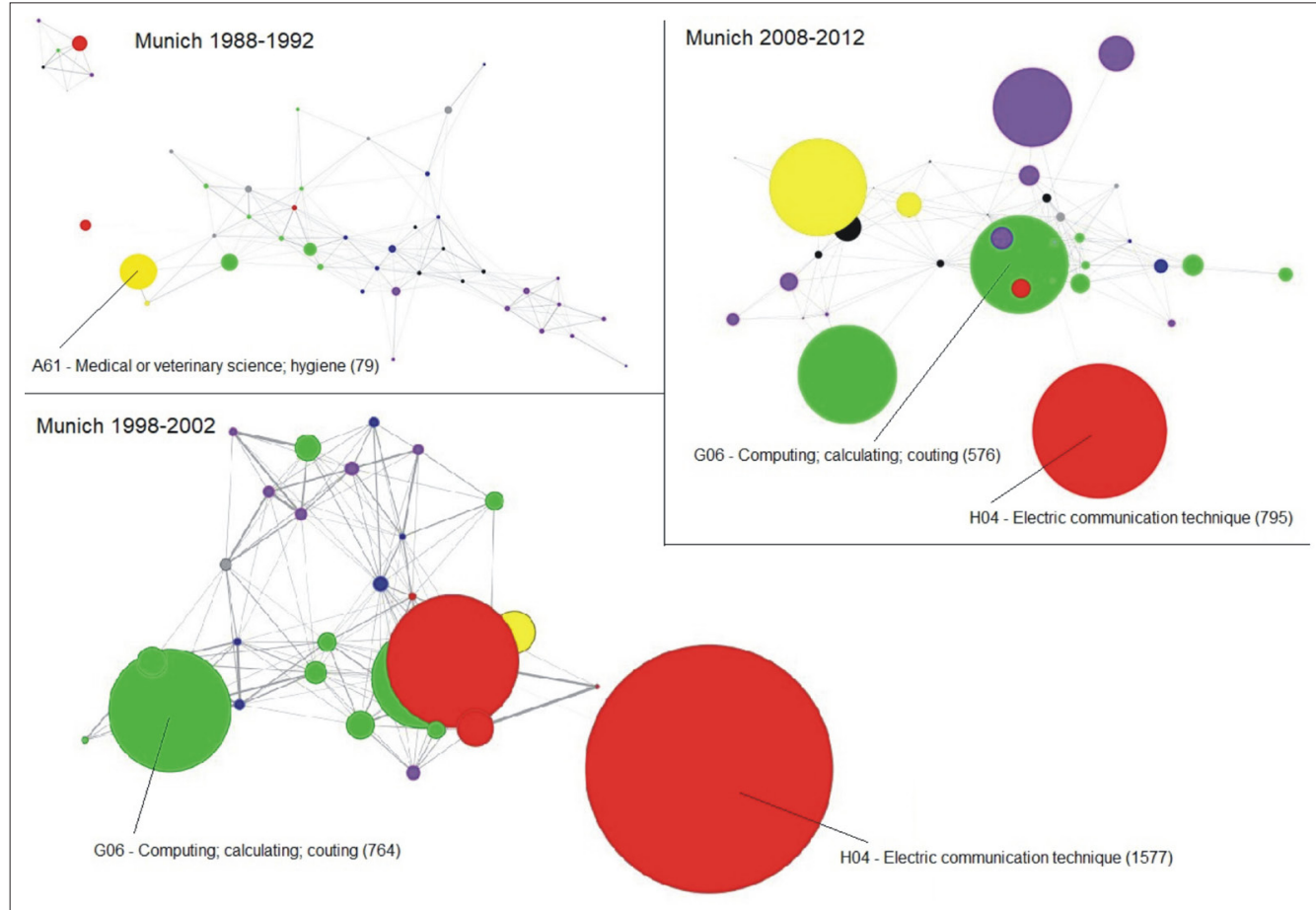

Fig. 3: Munich knowledge space (Note: The nodes are scaled to allow comparison between the periods. The numbers in brackets indicate the number of patents)

Source: authors' elaboration using data from OECD (2016) 
a few NUTS2 regions witnessed growth in specialisation and these are Franken, Lower Franconia, Bremen, Darmstadt, Kassel, Detmold, Trier and Chemnitz.

\subsection{Knowledge space and smart specialisation strategies in Munich, Düsseldorf and Oberes Elbtal / Osterzgebirge}

Since NUTS1 and even NUTS2 regions are variegated in terms of their size, area and economic and innovation output, we will illustrate the technological trajectories in three regional planning units: Munich, Düsseldorf and Oberes Elbtal/Osterzgebirge (Dresden). Munich is a hightech region with the highest number of patents and diversified industrial structure. Düsseldorf is considered as highly innovative with the third highest number of patents in Germany, although part of it is located in the old industrial area of the Ruhr, which has undergone economic restructuring. Dresden is an emerging region located in Saxony, one of the Eastern German states. These three regions do not provide a representative sample and are used only as illustrations. We map the evolution of the knowledge space and average relatedness in the three periods. Only patent classes that exhibit relative specialisation based on the RTA measure (revealed technological advantage: see Section3, above) have been chosen. We then compare these technological trajectories to existing smart specialisation strategies. In Germany, smart specialisation policies are set at the level of individual states (NUTS1 regions). Therefore, we also examine patenting and RTA in patents at that state level.

\subsubsection{Munich}

The Greater Munich planning region is located in Bavaria, and includes the city of Munich as well as surrounding districts (e.g. Erding, Dachau) among the most densely populated areas. Munich is considered to be one of the largest high-tech clusters in Europe with a major focus on ICT, automotive and aviation, as well as medical engineering and financial services. Large domestic and foreign enterprises coexist with Small and Medium Enterprises (SMEs), with the largest companies (and patent applicants) in the region including BMW, General Electric, Google and Siemens. Further, two major research organisations, the Max Planck Society and the Fraunhofer Society, have their headquarters in Munich, for which patents are filed (Baier et al., 2013). As the knowledge space (see Fig. 3) indicates, there has been a significant rise in the patent applications since the first period, as well as a change in industrial orientation. Whereas at the turn of the 1990s there were almost 50 patent classes with RTA, in 2008-2012 there were fewer than 40. The region has lost RTA in Chemicals (black) and Industrial processes (blue). The Electronics industry (red) has become much more important despite a decline in the latest period, while Instruments (green) are rising steadily. What is specific in all periods is the fact that the patent class "H04-Electric communication technique", the biggest one in the last two periods, is separated from all other nodes, indicating the absence of co-occurrence with other patent classes. This might be related to research activities of multinational enterprises and should be further explored. On the other hand, Instruments and Mechanical engineering, machines, transport are getting closer, which may reflect the upcoming trend of industry 4.0 (robotisation, automatisation). The average relatedness increased between 1988-1992 and 1998-2002 from 0.044 to 0.061 , but declined again to 0.045 in the period 2008-2012.

\subsubsection{Düsseldorf}

Part of the Düsseldorf planning unit is located in one of the oldest industrial regions and a major urban area in Europe - the Ruhr: Wesel county and the cities of Duisburg, Essen, Mülheim an der Ruhr and Oberhausen are all part of the Ruhr conurbation. Since the 1970s, the Ruhr area has undergone extensive restructuring from a coal and steel-based economy to a more diversified service economy. The city triangle of Remscheid-Solingen-Wuppertal is still largely manufacturing-oriented, whereas the cities of Mönchengladbach and Krefeld have experienced the decline of a once-dominant textile industry. Düsseldorf has traditionally been more service oriented and is one of the major telecommunication centres in Germany, as well as a centre of life sciences (Hospers, 2004; Rehfeld and Nordhause-Janz, 2017). From Figure 4, one can see that the knowledge space reflects the changing industrial structure. While Industrial processes (blue), Chemicals and materials (black) and Mechanical engineering, machines, transport (purple) dominated at the turn of the 1990s, the role of Pharmaceuticals and biotechnology (yellow) has increased significantly. Several major pharmaceutical and biotechnological companies are located in Düsseldorf (Qiagen, Monsato, Abbott). In both of the periods 19982002 and 2008-2012, the patent category "A61-Medical and veterinary science" had the highest number of patents. The category "C12-Biochemistry" class was also significant, as well as "C08-Organic macromolecular compounds". Over the whole period, the average relatedness has risen slightly from the late 1980 s and has been relatively stable since the second period (0.033). Düsseldorf continues to be the most diversified of the three planning units under exploration here, which is understandable given the high variability of the planning unit.

\subsubsection{Oberes Elbtal/Osterzgebirge}

Oberes Elbtal/Osterzgebirge includes the city of Dresden and its neighbouring districts. As part of the former German Democratic Republic, the major focus was on heavy industry and there were almost no EPO patent applications prior to 1990. Saxony was successful in attracting a number of major manufacturing companies, as well as institutes of national research organisations, to the region, as it carried out the most successful transformation among Eastern German regions (Kroll et al., 2016). The automobile, machinery and metal production industries continue to be important, along with the significant growth of the electronics sector. Semiconductor cluster Silicon Saxony, which was set up in 2000 , is internationally renowned and has won public support from both federal and European levels. From the knowledge space, it is obvious that there is a continuous rise of patent applications: see Figure 5 . In 1988-1992, a few patent classes with RTA were in Mechanical engineering, machines, transport (purple) and Industrial processes (blue). In later periods, Electronics, electrical engineering (red), followed by Instruments (green) and Chemicals and materials (black), started to dominate. Since general mechanical engineering is considered to be the least complex and digital communication the most complex technology (Balland and Rigby, 2017), this signifies a move towards more complex technologies in Dresden. More specifically, the most patent applications in the period 20082012 were in the category "H01-Basic electric elements", with a decline from the earlier period. On the other hand, applications in the patent class "G01-Measuring, testing" have been rising steadily. This region has also witnessed 


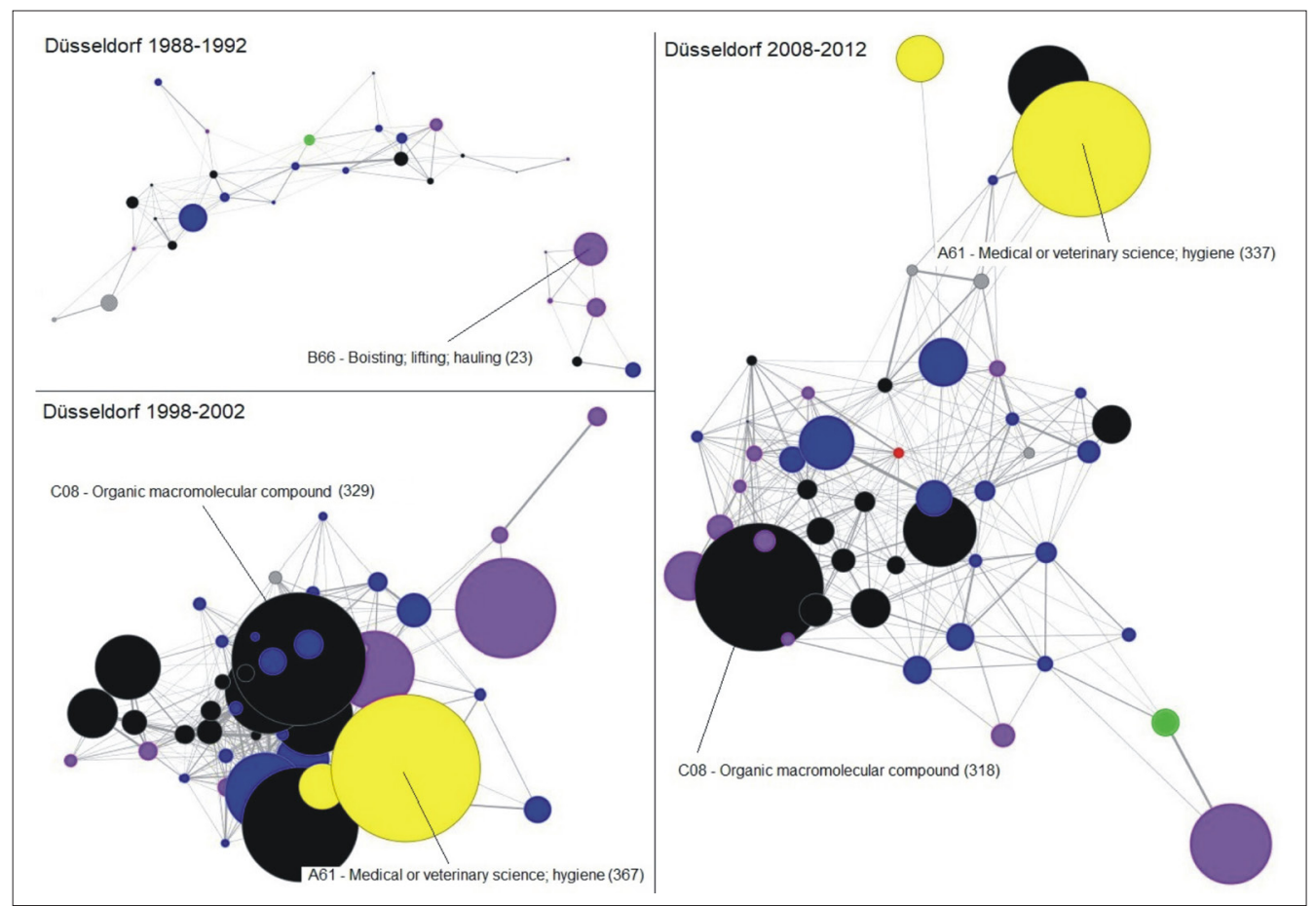

Fig. 4: Düsseldorf knowledge space (Note: The nodes are scaled to allow comparison between the periods. The numbers in brackets indicate the number of patents.)

Source: authors' elaboration using data from OECD (2016)

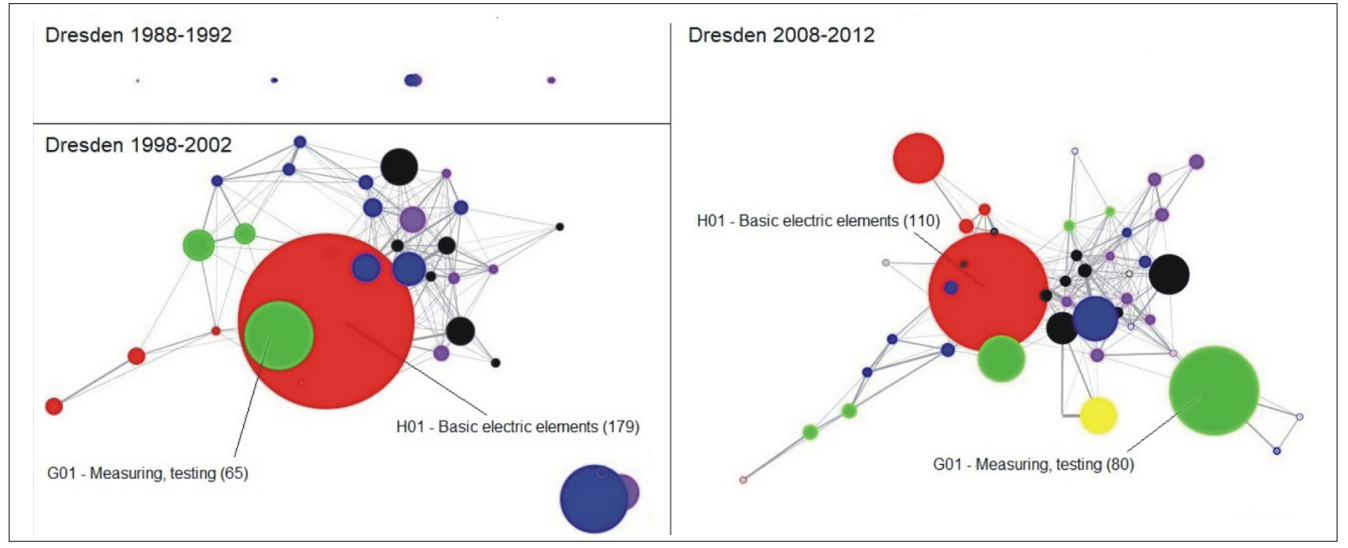

Fig. 5: Oberes Elbtal/Ostersgebirge knowledge space (Note: The nodes are scaled to allow comparison between the periods. The numbers in brackets indicate the number of patents.)

Source: authors' elaboration using data from OECD (2016)

large R\&D investment, reaching 4.1\% of GDP (OECD, 2017), stemming from national cross-subsidies as well as European structural funds. This can be related to the emergence of several high-tech parks and innovative companies such as Sunfire, a Dresden-based firm focusing on the conversion of chemical energy from a gaseous fuel into electricity. We can thus expect a further rise in the Chemicals, materials category. The average knowledge relatedness has increased significantly from the early period, with a decline in the last period. This can signify diversification to new technological fields, for example, energy-related ones, which are a national priority also due to the 'Energiewende' (German energy transition).

\subsection{Smart specialisation strategies in German regions}

German states have experience with regional innovation policies, but the RIS3 are the first legally binding framework documents. It is an evidence-based regional innovation strategy, which includes the already-existing structures, processes and experiences. In Germany, there are large variations between the regions, affected by the size, history and the decentralised education and research system. The knowledge space as described above confirms the large heterogeneity between German regions. Taking the case of Bavaria, the innovation policy in Munich focuses on the support of start-ups and regional clusters, and particularly the promotion of networking among SMEs. This is in line with the "Bavarian Cluster Campaign", which started in 2006. Kiese (2012) has identified 19 clusters in Bavaria. In terms of the smart specialisation policy, the sectoral focus of the Bavarian policy is rather broad, although there is a move towards a more system-oriented regional strategy development process (Baier et al., 2013). Whereas priorities have been set at the state level and are listed in the EU Eye@RIS3 tool, the main Bavarian document on research and innovation from 2011 does not mention 
smart specialisation nor define priority sectors (Bayerische Staatsregierung, 2011). The major target areas in Bavaria are ICT, biotechnology, efficient production systems and clean technologies, as well as innovative technology-based services. If we look at patent classes where Bavaria has a revealed technology advantage, more traditional sectors are leading (see Tab. 2). Nonetheless, the RIS3 priority sectors are in general the technological areas in Munich which have risen and become more related over the examined period (see above). Since the strategic document did not explicitly describe all smart specialisation principles, a special supporting paper has been published recently by the Bavarian government (European Commission, 2018).

The North-Rhine Westphalia Innovation strategy is derived from the smart specialisation concept (EFRE NRW, 2014). The first innovation strategy in North-Rhine Westphalia was passed in 2006 and revised in 2010, and prior to the RIS3, prospective industries were already identified. The RIS3 document in North-Rhine Westphalia has been widely discussed with stakeholders, and it has incorporated previous innovation policies. Priorities set for this region include health, life sciences, media and creative industries, as well as ICT, and the energy and environmental industry. Similar to Bavaria, North-Rhine Westphalia has values of RTA in more traditional sectors such as metallurgy, although it is more difficult to relate services such as creative industries to patent classes. Overall, RIS3 priorities are set for the whole state and the document does not allow the researcher to use lower geographical levels. Several of RIS3 priorities are the technology areas, with significant growth potential in Düsseldorf.

Unlike the case of Bavaria, no large-scale R\&D strategies were implemented in Saxony. Although Saxony did not introduce an innovation strategy in the 2000s, its 1992 "Guidelines for Technology Policy" had already identified nine technology fields with potential, and its policies incorporated a "process of entrepreneurial discovery" before such a requirement had been raised externally. Thus, Saxony has been successfully implementing smart specialisation strategies years before the term was coined (Kroll et al., 2016). Further, the ex-ante conditionality of RIS3 contributed to the fact that the policy bears a stronger smart specialisation approach. Defined key enabling technologies of the state are related to its industrial orientation and include ICT, biotechnology, nanotechnology, new materials or microelectronics and photonics (Freistaat Sachsen, 2013). The match between RTA in patents and RIS3 priorities is stronger than in the two previously discussed states (see Tab. 2). Smart specialisation strategies can only be successful when all relevant stakeholders are involved and they also need to integrate well with preexisting strategies and policies. This requires that regional governments act as mediators as well as arbitrators (Kroll et al., 2016). This can be problematic in Saxony, where clusters, which often serve as implementation vehicles, are absent (Koschatzky et al. 2017). On the other hand, highly innovative Bavaria does not seem to stress smart specialisation in its innovation policies.

The choice of priority technology areas is weakly described in the two other regions. In the Saxony Innovation Strategy, it is based on innovation intensity and the sales of new products, while in North-Rhine Westphalia the choice is based mostly upon employment shares in industries. Thus, there is no unified methodology for the identification of prospective industries. Specific to Germany is that the RIS3 strategies are set for large regions. There are 11 regions in the EU S3 platform; thus Germany has the same number of RIS3 regions as Sweden. As an example, the population of North-Rhine Westphalia is almost 18 million, i.e. 1.8 times that of Sweden. Hence, the inevitable question is whether a finer geographical level of aggregation would not be more appropriate.

\begin{tabular}{|c|c|c|c|c|c|}
\hline \multicolumn{2}{|c|}{ Bavaria } & \multicolumn{2}{|c|}{ North-Rhein Westphalia } & \multicolumn{2}{|c|}{ Saxony } \\
\hline RTA in patent classes & RIS3 priorities & RTA in patent classes & RIS3 priorities & RTA in patent classes & RIS3 priorities \\
\hline Instrument details & $\begin{array}{l}\text { Efficient } \\
\text { production } \\
\text { technologies } \\
\text { (robotics...) }\end{array}$ & $\begin{array}{l}\text { Furnaces, kilns, } \\
\text { ovens }\end{array}$ & $\begin{array}{l}\text { Machine and plant } \\
\text { engineering }\end{array}$ & Crystal growth & New materials \\
\hline $\begin{array}{l}\text { Writing or drawing } \\
\text { implements }\end{array}$ & Life sciences & $\begin{array}{l}\text { Sewing, } \\
\text { embroidering, tufting }\end{array}$ & Life sciences & $\begin{array}{l}\text { Generating or } \\
\text { transmitting } \\
\text { mechanical vibrations }\end{array}$ & $\begin{array}{l}\text { ICT and digital } \\
\text { communication }\end{array}$ \\
\hline $\begin{array}{l}\text { Explosive or thermic } \\
\text { compositions }\end{array}$ & ICT & Metallurgy of iron & Health & Nanotechnology & Nanotechnology \\
\hline Bookbinding, albums & $\begin{array}{l}\text { Innovative } \\
\text { technology-based } \\
\text { services }\end{array}$ & Locks, keys, safes & $\begin{array}{l}\text { Media and creative } \\
\text { industries }\end{array}$ & Horology & $\begin{array}{l}\text { Microelectronics } \\
\text { including organic } \\
\text { and polymer } \\
\text { electronics }\end{array}$ \\
\hline Footwear & Clean technologies & $\begin{array}{l}\text { Oils, detergents, } \\
\text { candles }\end{array}$ & ICT & Headwear & Biotechnology \\
\hline $\begin{array}{l}\text { Nuclear physics/ } \\
\text { engineering }\end{array}$ & $\begin{array}{l}\text { New materials, } \\
\text { nano- and micro- } \\
\text { technology }\end{array}$ & Metallurgy other & New materials & Weaving & Photonics \\
\hline $\begin{array}{l}\text { Musical instruments, } \\
\text { acoustics }\end{array}$ & & $\begin{array}{l}\text { Mechanical metal- } \\
\text { working }\end{array}$ & $\begin{array}{l}\text { Energy and } \\
\text { environmental } \\
\text { industry }\end{array}$ & Hydraulic engineering & $\begin{array}{l}\text { Advanced } \\
\text { production } \\
\text { technologies }\end{array}$ \\
\hline
\end{tabular}

Tab. 2: RIS3 priorities and RTA in patents classes in Bavaria, North-Rhine Westphalia and Sachsen (Note: Grey cells indicate the match between RIS3 priorities and patent classes with RTA.)

Source: European Commission, 2018; OECD, 2016 
In summary, German states do have experience with regional innovation policies. As their regional RIS3 strategies document, their attitude towards smart specialisation can be reluctant. This is because they often prefer practically proven policies to new unproven EU guidelines, which can be viewed as inappropriate for the German context (Kroll et al., 2016).

Technological specialisation is affected by processes of creative destruction, which affect the connections between technologies and leads to the entry/selection/exit of companies to/from industries, with exit and selection leading to a rise in specialisation (Kogler et al., 2017). Therefore, smart specialisation policies need to be frequently re-assessed. Kogler et al. (2017) confirm that regions are more likely to enter technology classes that are close to existing core knowledge, and exit technology classes that are further from the core in the knowledge space. Technological diversification in the region is also affected by extra-regional linkages. When these knowledge inflows are related to existing regional specialisation, they foster growth (Ponds et al., 2009). The smart specialisation concept also promotes technological diversification into closely-related sectors to the existing dominant technologies in line with evolutionary economic geography (Boschma and Frenken, 2011). The knowledge space can thus be used to identify complementarities within a region's knowledge base.

In terms of prospective industries, the most indistinct categories in Germany's knowledge space are Electronics and Instruments, in line with the increasing digitisation and automatisation in the global economy. Germany is lagging behind in Electronics in comparison to the European average (in relative terms), however, and it should also pay more attention to the service sector, particularly ICT, although it is already a priority based on the Tech strategy. Greater focus on Electronics and ICT should be more preferred in areas which are already strong in this sector such as Upper Bavaria (Munich). Overall, smart specialisation policy recommendations should vary in different places since no 'one-size-fits-all' policy works, and they need to engage with local entities to become a partnership-based policy process of discovery and learning - on the part of both policy makers and entrepreneurs (McCann and Ortega-Argilés, 2015). The marked variations of RIS3 strategies in German states highlight the methodological shortcomings of the smart specialisation policy. This is not only related to the identification of prospective industries, but also to the choice of the most appropriate geographical level for policies.

\section{Conclusions}

Germany is a large country with important variations between the regions in terms of their size, economic activity and innovation output. Machinery and transportation industries have increased their significance since the 19881992 period. Core technological regions such as BadenWürttemberg, Bavaria and North Rhein-Westphalia have increased their dominance over the period and account for almost $74 \%$ of German EPO applications. At the NUTS2 level, the most innovative regions are Upper Bavaria, Stuttgart and Düsseldorf. The differences between East and West Germany are still profound, with the former Eastern states accounting for just 6\% of EPO applications.

Over the more than twenty years examined (1988-1992, 1998-2002 and 2008-2012), specialisation in Germany measured by the average relatedness measures increased by $10 \%$ (particularly in Consumer goods and Electronics), despite a slight decline over the last two periods. Kogler et al. (2017) found increasing specialisation in EU15 NUTS2 regions over the whole period from 1981 to 2005. There is, however, considerable heterogeneity in terms of knowledge relatedness in German regions. Both at the NUTS1 and NUTS2 level, half of the regions have witnessed a decrease in specialisation, from both the former East and West Germany. There are also differences between highly innovative regions, with some of them being highly specialised, others being more diversified. Further research is thus needed to analyse whether the decline in specialisation in the last decade is specific only to Germany as a whole, or whether the pace of specialisation has slowed or stopped also in other countries.

The detailed analysis of the evolution of the knowledge space in three planning regions (Munich, Düsseldorf, Oberes Elbtal/Osterzgebirge) has demonstrated the changes in their technological trajectories over the twenty years, as well as in the levels of knowledge relatedness (specialisation). We have also identified the heterogeneity of their policy framework conditions - leading to variations in the smart specialisation strategies in German regions. In highly innovative Bavaria, it was largely absent although a new document reflecting smart specialisation guidelines has been elaborated recently. In Saxony and North-Rhine Westphalia, the way of choosing strategic sectors differs (employment shares vs. innovation intensity and new products) and is not described in detail. Further, the population size of German RIS3 regions is highly variegated and in three of these regions exceeds 10 million. This points to insufficiently developed smart specialisation methodology.

We believe that more focus should be given to the theory, as well as finding new tools for the identification of prospective industries. This needs to be based on indepth analyses of the actual status quo and be regularly reassessed. The relatedness measures and the knowledge space could be used to identify sectors closest to the knowledge core, because there is a high probability that regions will enter these sectors compared to those that are further apart in the knowledge space and such sectors foster growth (Kogler et al., 2017). Further, diversification into more complex technologies is associated with greater economic benefits (Balland et al., 2017). This could be very useful particularly in Saxony, due to its on-going restructuring and lower experience with innovation policies compared to the former Western German states. In Germany, there has already been an increasing overlap of Electronics and Instruments categories. This is in line with greater automatisation and digitalisation. Furthermore, in manufacturing-oriented Germany, a focus on ICT services should be further developed, particularly in regions with already existing capabilities, such as Munich.

There are differences between countries and industries in terms of propensity to patent, and services are in general underestimated in patents. Although in Germany such industries, where the propensity to patent is the highest, dominate, in peripheral regions patenting is very low. Using the concepts of knowledge relatedness and complexity would guarantee a region's technological diversification opportunities on the basis of embeddedness, relatedness and connectivity. For such purposes, patent data should be best combined with other indicators to overcome its limitations. Smart specialisation policies also need to reflect 
extra-regional linkages within global production networks, particularly in export-oriented Germany. Overall, special attention should be given to peripheral regions in the EU, regions where establishing effective smart specialisation policy is even more complicated.

\section{Acknowledgments}

The authors acknowledge support from the Internal Grant IG210016 "The impact of growing global middle class on selected developing and developed regions".

\section{References:}

ACS, Z., AUDRETSCH, D. B. (1989): Patents as a measure of innovative activity. Kyklos, 42(2): 171-180.

AGHION, P., HOWITT, P. (1990): A model of growth through creative destruction (No. 3223). Cambridge, National Bureau of Economic Research.

ARCHIBUGI, D., PIANTA, M. (1992): Specialization and size of technological activities in industrial countries: The analysis of patent data. Research Policy, 21(1): 79-93.

ASHEIM, B. T., GERTLER, M. S. (2005): The geography of innovation: regional innovation systems. In: Fagerberg, J., Mowery, D. C., Nelson, R. R. [eds.] (2005): The Oxford handbook of innovation (pp. 291-317). Oxford, Oxford University Press

AUDRETSCH, D. B., FELDMAN, M. P. (1996): R\&D spillovers and the geography of innovation and production. The American economic review, 86(3): 630-640.

BAIER, E., KROLL, H., ZENKER, A. (2013): Templates of smart specialization: Experiences of place based regional development strategies in Germany and Austria. (Working Papers Firms and Region, R5/2013). Karlsruhe, Fraunhofer Institutefor Systemsand Innovation Research ISI [online] [cit. 10.05.2018]. Available at: https://www. econstor.eu/bitstream/10419/74482/1/745637779.pdf

BALLAND, P.A., RIGBY, D. (2017): The geography of complex knowledge. Economic Geography, 93(1): 1-23.

BALLAND, P. A., BOSCHMA, R., CRESPO, J., RIGBY, D. L. (2017): Relatedness, knowledge complexity and technological opportunities of regions: A framework for smart specialisation. Papers in Evolutionary Economic Geography. 17.17. Utrecht, Utrecht University.

BATHELT, H., MALMBERG, A., MASKELL, P. (2004): Clusters and knowledge: local buzz, global pipelines and the process of knowledge creation. Progress in human geography, 28(1): 31-56.

BAYERISCHE STAATSREGIERUNG (2011): Gesamtkonzept für die Forschungs-, Technologie- und Innovationspolitik der Bayerischen Staatsregierung. [online] [cit. 10.05.2018]. Available at: http://s3platform. jrc.ec.europa.eu/documents/20182/229963/DE_Bayern_ RIS3_201105_Final.pdf/dc9a6e62-c1c1-4a 2 d-b6247fccf3fa0988)

BEAUDRY, C., SCHIFFAUEROVA, A. (2009): Who's right, Marshall or Jacobs? The localization versus urbanization debate. Research policy, 38(2): 318-337.

BEISE, M., STAHL, H. (1999): Public research and industrial innovations in Germany. Research policy, 28(4): 397-422.
BOSCHMA, R. (2005): Proximity and innovation: a critical assessment. Regional studies, 39(1): 61-74.

BOSCHMA, R., FRENKEN, K. (2011): The emerging empirics of evolutionary economic geography. Journal of economic geography, 11(2): 295-307.

BOSCHMA, R., IAMMARINO, S. (2009): Related variety, trade linkages, and regional growth in Italy. Economic Geography, 85(3): 289-311.

BOSCHMA, R., MINONDO, A., MIKEL, N. (2013): Related variety and regional growth in Spain, Papers in Regional Sciences, 91 (2): 241-256.

BRESCHI, S., LISSONI, F., MALERBA, F. (2003): Knowledgerelatedness in firm technological diversification. Research Policy, 32(1): 69-87.

BRÜLHART, M.; TRAEGER, R. (2005): An account of geographic concentration patterns in Europe. Regional Science and Urban Economics, 35(6): 597-624.

COHEN， W. M., LEVINTHAL， D. A. (1990): Absorptive capacity: A new prospective on learning and innovation. Administrative science quarterly, 128-152.

COHEN, W. M., GOTO, A., NAGATA, A., NELSON, R. R., WALSH, J. P. (2002): R\&D spillovers, patents and the incentives to innovate in Japan and the United States. Research policy, 31(8-9): 1349-1367.

CORONADO, D., FLORES, E. MARTÍNEZ, M. Á. (2017). The role of regional economic specialization in the production of university-owned patents. Annals of Regional Science. 59(2): 513-533.

CYTOSCAPE (2017): Cytoscape Manuals [online]. Available at: http://www.cytoscape.org/manual/

EFRE NRW (2014): Regionale Innovationsstrategie des Landes Nordrhein Westfalen im Rahmen der EUStrukturfonds 2014-2020 [online]. Available at: https:// www.efre.nrw.de/fileadmin/user_upload/Programmtexte/ Regionale_Innovationsstrategie.pdf

EUROPEAN COMMISSION. (2016): RIO Country Report 2016: Germany [online]. Available at: https://rio. jrc.ec.europa.eu/en/file/10849/download?token $=\mathrm{H}_{-}$ FUucsh

EUROPEAN COMMISSION (2018): Smart Specialization Platform [online]. Available at: s3platform.jrc.ec.europa.eu

FORAY, D., DAVID, P.A.; HALL, B. (2009): Smart specialisation-the concept. Knowledge economists policy brief, 9(85): 100 .

FREISTAAT SACHSEN (2013): Innovationsstrategie des Freistaates Sachsen [online]. Available at: http:// www.innovationsstrategie.sachsen.de/download/ Innovationsstrategie_des_Freistaates_Sachsen.pdf

FRENKEN, K., BOSCHMA, R.A. (2007): A theoretical framework for evolutionary economic geography: industrial dynamics and urban growth as a branching process. Journal of economic geography, 7(5): 635-649.

GERTLER, M. S. (2003): Tacit knowledge and the economic geography of context, or the undefinable tacitness of being (there). Journal of economic geography, 3(1): 75-99.

GRILICHES, Z. (1998): R\&D and productivity. Cambridge, National Bureau of Economic Research Books.

GRUPP, H. (1998). Foundations of the Economics of Innovation. Books. Edward Elgar Publishing. 
HALL, B. H., JAFFE, A. B., TRAJTENBERG, M. (2001): The NBER patent citation data file: Lessons, insights and methodological tools (No. 8498). Cambridge, National Bureau of Economic Research.

HIDALGO, C.A., KLINGER, B., BARABÁSI, A. L., HAUSMANN, R. (2007): The product space conditions the development of nations. Science, 317(5837): 482-487.

IAMMARINO, S., MCCANN, P. (2006): The structure and evolution of industrial clusters: Transactions, technology and knowledge spillovers. Research policy, 35(7): 1018-1036.

JOO, S. H., KIM, Y. (2010): Measuring relatedness between technological fields. Scientometrics, 83(2): 435-454.

KIESE, M. (2008): Mind the Gap: regionale Clusterpolitik im Spannungsfeld von wissenschaft, politik und praxis aus der perspektive der neuen politischen Ökonomie. Zeitschrift für wirtschaftsgeographie, 52(1): 129-145.

KIESE, M., WROBEL, M. (2011): A public choice prospective on regional cluster and network promotion in Germany. European Planning Studies, 19(10): 1691-1712.

KIESE, M. (2012): Regionale Clusterpolitik in Deutschland: Bestandsaufnahme und interregionaler Vergleich im Spannungsfeld von Theorie und Praxis. Marburg, Metropolis.

KOGLER, D. F., RIGBY, D. L., TUCKER, I. (2013): Mapping knowledge space and technological relatedness in US cities. European Planning Studies, 21(9): 1374-1391.

KOGLER, D. F., ESSLETZBICHLER, J., RIGBY, D. L. (2017): The evolution of specialization in the EU15 knowledge space. Journal of Economic Geography, 17(2): 345-373.

KOGLER, D., WHITTLE, A. (2018): The Geography of Knowledge Creation: Technological Relatedness and Regional Smart Specialization Strategies. In: Paasi, A., Harrison, J., Jones, M. [eds.] (2018): Handbook on the Geographies of Regions and Territories. Cheltenham, Edward Elgar Publishing.

KOSCHATZKY, K., KROLL, H., SCHNABL, E., STAHLECKER, T. (2017): Cluster policy adjustments in the context of smart specialization? Impressions from Germany. The Life Cycle of Clusters: A Policy Prospective, 173.

KROLL, H., BÖKE, I., SCHILLER, D., STAHLECKER, T. (2016): Bringing owls to Athens? The transformative potential of RIS3 for innovation policy in Germany's Federal States. European Planning Studies, 24(8): 1459-1477.

LETEN, B., BELDERBOS, R., VAN LOOY, B. (2007): Technological diversification, coherence, and performance of firms. Journal of Product Innovation Management, 24(6): 567-579.

MARTIN, R., SUNLEY, P. (2006): Path dependence and regional economic evolution. Journal of economic geography, 6(4): 395-437.

MASKELL, P., MALMBERG, A. (2007): Myopia, knowledge development and cluster evolution. Journal of Economic Geography, 7(5): 603-618.

MORGAN, K. (2015): Smart Specialisation: Opportunities and Challenges for Regional Innovation Policy, Regional Studies 49(3): 480-482.
McCANN, P., ORTEGA-ARGILÉS， R. (2015): Smart specialization, regional growth and applications to European Union cohesion policy. Regional Studies, 49(8): 1291-1302.

NAUWELAERS, C., MAGRO, E., ARANGUREN, M. J., NAVARRO, M., WILSON, J., TRIPPL, M., HEALY, A. (2014): Smart specialization for regional innovation. Underpinning effective strategy design: Reflection paper. Workpackage 4. Seventh Framework Programme.

NEFFKE, F., HENNING, M., BOSCHMA, R. (2011): How do regions diversify over time? Industry relatedness and the development of new growth paths in regions. Economic Geography, 87(3): 237-265.

OECD (2011): OECD Science, Technology and Industry Scoreboard 2011: Innovation and Growth in Knowledge Economies. Paris, OECD.

OECD (2013): Innovation-driven Growth in Regions: The Role of Smart Specialisation [online]. Available at: http://www.oecd.org/sti/inno/smart-specialisation. pdf\#page 113

OECD (2016): OECD REGPAT database [online]. Available at: https://www.oecd-ilibrary.org/science-and-technology/ the-oecd-regpat-database_241437144144

OECD (2017): Innovation and technology statistics [online]. Available at: https://data.oecd.org/innovation-andtechnology.htm

ORTEGA-ARGILÉS, R. (2012): The transatlantic productivity gap: a survey of the main causes. Journal of Economic Surveys, 26(3): 395-419.

PAVITT, K. (1982): R\&D, patenting and innovative activities: a statistical exploration. Research Policy, 11(1): 33-51.

PETERS, B. (2008): Innovation and firm performance: An empirical investigation for German firms. Springer Science \& Business Media.

PONDS, R., OORT, F. V., FRENKEN, K. (2009): Innovation, spillovers and university-industry collaboration: an extended knowledge production function approach. Journal of Economic Geography, 10(2): 231-255.

RIGBY, D. L., ESSLETZBICHLER, J. (1997): Evolution, process variety, and regional trajectories of technological change in US manufacturing. Economic Geography, 73(3): 269-284.

RIGBY, D. L. (2015): Technological relatedness and knowledge space: entry and exit of US cities from patent classes. Regional Studies, 49(11): 1922-1937.

SANTOALHA, A. (2016): New Indicators of Smart Specialization: A related diversification approach applied to European Regions .Working Paper No. 20161220. Centre for Technology, Innovation and Culture, University of Oslo.

SAXENIAN, A. (1996): Regional advantage. Harvard University Press.

SCHANKERMAN, M., PAKES, A. (1985): Estimates of the Value of Patent Rights in European Countries During thePost-1950 Period. Economic Journal, 96(384): 1052-1076.

SCHERER, F. M. (1982): Inter-industry technology flows and productivity growth. The review of economics and statistics, 627-634. 
SONN, J.W.; STORPER, M. (2008): The increasing importance of geographical proximity in knowledge production: an analysis of US patent citations, 19751997. Environment and Planning A, 40(5): 1020-1039.

SUEDEKUM, J. (2006): Concentration and specialization trends in Germany since re-unification. Regional Studies, 40(8): 861-873.

TANRIVERDI, H., VENKATRAMAN, N. (2005): Knowledge relatedness and the performance of multibusiness firms. Strategic Management Journal, 26(2): 97-119.

TEECE, D. J., RUMELT, R., DOSI, G., WINTER, S. (1994): Understanding corporate coherence: Theory and evidence. Journal of economic behavior \& organization, 23(1): 1-30.
VLČKOVÁJ., NOSEK, V., NOVOTNÝ, J. LUPÍŠEK, A. (2015):

Carbon dioxide emissions embodied in international trade in Central Europe between 1995 and 2008. Moravian Geographial Reports 23(4): 2-13.

VLČKOVÁ, J., KASPŘÍKOVÁ, N. (2015): Knowledge relatedness and knowledge space based on EPO patents. Prague economic papers, 2015(4): 399-415.

\section{Please cite this article as:}

VLČKOVÁ, J., KASPŘÍKOVÁ, N., Markéta VLČKOVÁ, M. (2018): Technological relatedness, knowledge space and smart specialisation: The case of Germany. Moravian Geographical Reports, 26(2): 95-108. Doi: 10.2478/mgr-2018-0008. 